\title{
Function and lifespan of corpora lutea in ewes treated with exogenous oxytocin
}

\author{
R. A. Milvae ${ }^{1}$, R. T. Duby ${ }^{2}$, J. P. Tritschler II ${ }^{2}$, R. F. Pekala ${ }^{2}$, \\ G. G. Gnatek ${ }^{2}$, S. L. Bushmich ${ }^{1}$ and D. T. Schreiber, Jr ${ }^{1}$ \\ ${ }^{1}$ Department of Animal Science, University of Connecticut, Storrs, CT 06269-4040, USA; and \\ ${ }^{2}$ Department of Veterinary Science, University of Massachusetts, Amherst, MA 01003, USA
}

\begin{abstract}
Summary. Oxytocin was administered to Dorset and Shropshire ewes in one experiment and to Dorset ewes in a further 4 experiments. In Exp. 1, concentrations of plasma progesterone and lengths of the oestrous cycle in ewes given oxytocin subcutaneously twice a day on Days $0-3,2-5,4-7,6-9,8-11,10-13,12-15$ or $14-17$ were similar to those of control ewes. In Exp. 2, intraluteal infusions of oxytocin from Day 2 to Day 9 after oestrus had no effect on concentration of progesterone, weight of CL collected on Day 9 or length of the oestrous cycle. In Exp. 3, intraluteal infusions of oxytocin on Days 10-15 after oestrus had no effect on weight of CL collected on Day 15. In Exp. 4, s.c. injections of oxytocin on Days 3-6 after oestrus had no effect on weight of $\mathrm{CL}$ collected on Day 9, concentrations of progesterone or length of the oestrous cycle. In Exp. 5, s.c. injections of oxytocin twice a day did not affect the maintenance and outcome of pregnancy in lactating and nonlactating ewes. Exogenous oxytocin, therefore, does not appear to affect luteal function at any stage of the ovine oestrous cycle although oxytocin has been reported by others to alter ovine $\mathrm{CL}$ function.
\end{abstract}

Keywords: ewe; corpus luteum; oxytocin

\section{Introduction}

Armstrong \& Hansel (1959) first reported inhibition by exogenous oxytocin of the bovine CL if administered during Days 2-6 of the oestrous cycle. These effects occurred only when oxytocin was administered during this critical period, and the presence of the uterus was required for its manifestation.

The CL of cows, sheep and other species contain high concentrations of oxytocin (reviewed by Wathes, 1984). Oxytocin, neurophysin and progesterone appear to be secreted simultaneously from the CL during the early and midluteal phases of the oestrous cycle in cattle (Schams et al., 1985) and sheep (Sheldrick \& Flint, 1981). Oxytocin concentration declines after luteolysis and is reported to be low in pregnant sheep (Wathes \& Swann, 1982). Flint \& Sheldrick (1982) and others have found that injections of prostaglandin (PG)F-2 $\alpha$ caused an immediate increase in ovarian venous concentrations of oxytocin.

These findings led to the hypothesis (Flint \& Sheldrick, 1983) that oxytocin is released in a pulsatile manner; this secreted luteal oxytocin binds to endometrial oxytocin receptors and results in the release of uterine PGF-2 $\alpha$, which stimulates further release of luteal oxytocin leading to luteolysis.

Reports on the effects of exogenous oxytocin on ovine CL function have been equivocal. Hatjiminaoglou et al. (1979) reported that exogenous oxytocin given on Days 1-7 of the oestrous cycle resulted in premature luteolysis and a reduction in the length of the oestrous cycle in some 
ewes. Conversely, Flint \& Sheldrick (1985) reported that continuous infusions of oxytocin on Days 13-21 of the oestrous cycle prolonged luteal lifespan by 7 days.

In the present experiments, we examined the effects of exogenous oxytocin, administered either as intraluteal infusions or s.c. injections, on luteal function at different stages of the ovine oestrous cycle.

\section{Materials and Methods}

\section{Experiment 1}

Normally cycling mature ewes (18 Dorset and 18 Shropshire, 4 ewes/treatment group) were randomly assigned to receive 50 U.S.P. units of synthetic oxytocin (Sigma Chemical, St. Louis, MO, USA) s.c. twice a day (07:00 and 19: $00 \mathrm{~h}$ ) on the following days of the oestrous cycle: Group 1, 0-3; Group 2, 2-5; Group 3, 4-7; Group 4, 6-9; Group 5 , 8-11; Group 6, 10-13; Group 7, 12-15; Group 8, 14-17; and Group 9, untreated control ewes. Plasma samples were collected daily via jugular venepuncture from Day 0 (oestrus) until the detection of subsequent oestrus by a vasectomized marker ram. Plasma concentrations of progesterone were determined by radioimmunoassay (Beal et al., 1980). The intra- and interassay coefficients of variation were 8.9 and $10.7 \%$, respectively. The sensitivity of the assay was $25 \mathrm{pg} / \mathrm{tube}$.

\section{Experiments 2-5}

Oestrous activity was monitored in Dorset sheep twice a day by introducing a vasectomized ram to the ewes. Ewes standing to be mounted were considered to be in oestrus and this was designated as Day 0 of the cycle.

To determine whether oxytocin affects the $\mathrm{CL}$ if infused directly into it (Exps 2 and 3), Alzet mini-osmotic pumps (ALZA, Palo Alto, CA, USA; model 1701) were prepared. The reservoir was filled with $0.2 \mathrm{ml}$ of a $2 \%$ solution of trypan blue in $0.9 \% \mathrm{NaCl}$. The flow moderator was inserted and connected to a length of Silastic tubing (Dow Corning 602-135, Midland, MI, USA) filled with oxytocin, $0.9 \% \mathrm{NaCl}$ or $0.5 \%$ chlorobutanol in $0.9 \% \mathrm{NaCl}$. The pumps were placed in sterile $0.9 \% \mathrm{NaCl}$ at $4^{\circ} \mathrm{C}$ overnight and movement of the dye from the reservoir to the tubing was taken as evidence that the pump was functional. Similarly, when the pumps were removed from the animals after the treatment period, presence of the dye throughout the tube was evidence that the test solution had been infused into the CL.

Pumps thus prepared were inserted into the $\mathrm{CL}$ of normally cycling ewes as follows. Ewes were anaesthetized ( $26 \mathrm{mg}$ pentobarbitone sodium $/ \mathrm{kg}$, i.v.) and placed in dorsal recumbency and the ovaries were exposed through a midventral incision and examined for the presence of CL. An 18-gauge needle was then used to puncture the tunica of the ovary lateral to the $\mathrm{CL}$ and then forced through the stroma into the CL to form a channel for the Silastic catheter. Immediately after withdrawal of the needle, the catheter was inserted into the CL through the channel formed by the needle. Once in place, it was anchored to the surface of the ovary by suturing through the tunica with 5-0 silk suture and one drop of Super Glue (Loctite Corporation, Cleveland, OH, USA). The body of the pump was then brought though the incision and placed subcutaneously lateral to the incision. When pumps were to be removed, the incision was reopened, the pump located and the catheter followed to the ovary. In all cases, the ovary was examined to determine whether the pump was in the CL or stroma, or had been pulled from the ovary. Only data on pumps in which the catheter was verified to be in the CL were used. To evaluate the system further, $250 \mathrm{~g}$ cloprostenol sodium/ $\mathrm{ml}$ (Estrumate, Mobay Corp., Shawnee, KS, USA) was infused into the CL of 2 ewes on Day 2 of the cycle. Both ewes returned to oestrus within $48 \mathrm{~h}$ of insertion and new $\mathrm{CL}$ were present on the ovaries when the pumps were removed on Day 9. Progesterone was not detected on Day 6.

\section{Experiment 2}

The effects of intraluteal infusion of oxytocin on Days 2-9 of the oestrous cycle were examined in 15 ewes prepared with intraluteal catheters. In all ewes, the number of $\mathrm{CL}$ at the time of pump insertion (Day 2 ) was reduced to 1 by excision of surplus CL. Nine ewes were infused with oxytocin $(0.855 \mathrm{i} . \mathrm{u} . / \mathrm{h})$ and 6 were infused with $0.5 \%$ chlorobutanol in $0.9 \% \mathrm{NaCl}$ (carrier for oxytocin). Pumps were removed and the $\mathrm{CL}$ collected and weighed from all chlorobutanoltreated ewes and 6 of the oxytocin-treated animals on Day 9 of the cycle. The remaining animals were allowed to return to oestrus. All ewes were bled on Day 6 and plasma was separated and assayed for progesterone by radioimmunoassay to assess luteal function.

\section{Experiment 3}

The effects of infusing oxytocin $(0 \cdot 215 \mathrm{i} . \mathrm{u} . / \mathrm{h})$ on Days $10-15$ of the oestrous cycle on $\mathrm{CL}$ regression were studied. Pumps were prepared containing oxytocin or $0.9 \%(\mathrm{w} / \mathrm{v}) \mathrm{NaCl}$ and inserted as described above. Of the 5 ewes treated in this experiment, 4 had $2 \mathrm{CL}$. One catheter containing oxytocin was placed in one $\mathrm{CL}$ while the other received saline 
solution. All pumps were removed on Day 15 and the CL collected and weighed. Oxytocin was infused into the only CL of the ewe with the single ovulation.

\section{Experiment 4}

The effects of s.c. injections of oxytocin ( 50 i.u./day) administered during Days 2-6 of the oestrous cycle were determined: 6 ewes were treated with oxytocin and 8 received $2.0 \mathrm{ml} 0.9 \% \mathrm{NaCl}$. Plasma samples were obtained on Day 6 after oestrus and the animals were allowed to return to oestrus. Two groups of 3 ewes each were treated as above except that they were laparotomized on Day 9 after oestrus and the CL removed and weighed.

\section{Experiment 5}

The effect of injections of oxytocin, 25 i.u. twice a day s.c. from Day 10 to 15 after mating, was determined in 9 nonlactating and 8 lactating ewes treated with oxytocin. Two lactating and 4 nonlactating ewes were injected twice a day from Day 10 to 15 of pregnancy with $2 \mathrm{ml}$ sterile $0.9 \% \mathrm{NaCl}$. All ewes were allowed to return to oestrus or to lamb.

\section{Statistical analysis}

Concentrations of progesterone in Exp. I were analysed by split-plot analysis of variance for repeated measurements (Gill \& Hafs, 1971) and Duncan's multiple range test. Differences in length of the oestrous cycle and CL weight between treatment groups were evaluated with Student's $t$ tests.

\section{Results}

\section{Experiment 1}

Treatment with oxytocin twice a day for any of the consecutive 4-day treatment periods did not affect $(P>0.05)$ concentrations of plasma progesterone on any day of the oestrous cycle. Concentrations of progesterone are shown in Table 1 for Days 8 and 12 of the cycle. Injections of oxytocin did not affect the length of the oestrous cycle in any of the treatment groups (Table 1).

Table 1. Concentration of plasma progesterone and length of the oestrous cycle in ewes treated with oxytocin twice a day (Exp. 1)

\begin{tabular}{|c|c|c|c|}
\hline \multirow{2}{*}{$\begin{array}{l}\text { Treatment } \\
\text { days }\end{array}$} & \multicolumn{2}{|c|}{ Conc. of progesterone $(\mathrm{ng} / \mathrm{ml})$} & \multirow{2}{*}{$\begin{array}{l}\text { Cycle length } \\
\text { (days) }\end{array}$} \\
\hline & Day 8 & Day 12 & \\
\hline $0-3$ & $1.15 \pm 0.06$ & $1.52 \pm 0.36$ & $16.25 \pm 0.48$ \\
\hline $2-5$ & $1.95 \pm 0.53$ & $1.89 \pm 0.29$ & $15.5 \pm 0.35$ \\
\hline $4-7$ & $1.30 \pm 0.13$ & $2.19 \pm 0.77$ & $16.0 \pm 0.0$ \\
\hline $6-9$ & $1.40 \pm 0.23$ & $1.88 \pm 0.49$ & $16 \cdot 5 \pm 1 \cdot 2$ \\
\hline $8-11$ & $1.72 \pm 0.60$ & $2.35 \pm 0.88$ & $15.75 \pm 0.95$ \\
\hline $10-13$ & $1.63 \pm 0.15$ & $1.96 \pm 0.12$ & $17.25 \pm 0.63$ \\
\hline $12-15$ & $1 \cdot 21 \pm 0.17$ & $1.31 \pm 0.09$ & $17.5 \pm 0.50$ \\
\hline $14-17$ & $1.30 \pm 0.05$ & $1.51 \pm 0.14$ & $16.0 \pm 0.41$ \\
\hline Untreated & $1 \cdot 14 \pm 0 \cdot 23$ & $1.30 \pm 0.48$ & $14 \cdot 75 \pm 1 \cdot 0$ \\
\hline
\end{tabular}

Values are means \pm s.e.m., 4 ewes/group.

\section{Experiment 2}

Continuous intraluteal infusion of oxytocin on Days 2-9 did not alter weights of CL collected on Day $9(P>0.05)$ or concentration of progesterone in plasma collected on Day 6 (Table 2 ). 
Table 2. Effect of continuous intraluteal infusion of oxytocin on Days 2-9 after oestrus on corpus luteum (CL) weight, plasma progesterone concentration and length of the oestrous cycle in ewes (Exp. 2)

\begin{tabular}{lcccc}
\hline Treatment & $\begin{array}{c}\text { No. of } \\
\text { ewes }\end{array}$ & $\begin{array}{c}\text { CL weight } \\
(\mathrm{mg})\end{array}$ & $\begin{array}{c}\text { Progesterone } \\
\text { on Day 6 } \\
(\mathrm{ng} / \mathrm{ml})\end{array}$ & $\begin{array}{c}\text { Cycle } \\
\text { length } \\
\text { (days) }\end{array}$ \\
\hline Oxytocin & 5 & $694 \cdot 6 \pm 76 \cdot 4$ & $2 \cdot 36 \pm 1 \cdot 03$ & - \\
Oxytocin & 4 & - & $1 \cdot 65 \pm 0.34$ & $16 \cdot 00 \pm 0$ \\
Chlorobutanol & 6 & $468 \cdot 1 \pm 107 \cdot 8$ & $2 \cdot 06 \pm 0.55$ & - \\
$0.9 \% \mathrm{NaCl}$ & 3 & $589.3 \pm 259 \cdot 0$ & & - \\
$0.9 \% \mathrm{NaCl}$ & 4 & - & $3.55 \pm 1.09$ & $16 \cdot 25 \pm 0.5$ \\
\hline
\end{tabular}

Values are means \pm s.e.m.

\section{Experiment 3}

Intraluteal infusions of oxytocin on Days 10-15 of the oestrous cycle had no effect on the weight of CL collected on Day 15 when compared with the saline-infused CL of the same ewe (Table 3).

Table 3. Effect of continuous intraluteal infusion of oxytocin on Days 10-15 after oestrus on corpus luteum (CL) weight in 6 ewes (Exp. 3)

\begin{tabular}{lcc}
\hline & \multicolumn{2}{c}{ CL weight (mg) } \\
\cline { 2 - 3 } Ewe no. & Oxytocin & Saline $(0.9 \%)$ \\
\hline $\mathrm{I}$ & 329 & 422 \\
2 & 349 & 378 \\
3 & 469 & 363 \\
4 & 312 & 426 \\
5 & 440 & 359 \\
6 & 567 & - \\
Mean \pm s.e.m. & $411 \pm 99$ & $389 \pm 32$ \\
\hline
\end{tabular}

\section{Experiment 4}

Subcutaneous injections of 50 i.u. oxytocin on Days 2-6 of the oestrous cycle did not affect the weights of CL collected on Day 9. Concentrations of plasma progesterone in oxytocin-treated ewes were similar to those in saline-injected ewes on Day 6 of the oestrous cycle. Injections of oxytocin did not affect the length of the oestrous cycle (Table 4).

Table 4. Effect of 50 i.u. oxytocin injected s.c. on Days 2-6 after oestrus on CL weight on Day 9, plasma progesterone concentration on Day 6 and length of the oestrous cycle in ewes (Exp. 4)

\begin{tabular}{lcccc}
\hline Treatment & $\begin{array}{c}\text { No. of } \\
\text { ewes }\end{array}$ & $\begin{array}{c}\text { CL weight } \\
(\mathrm{mg})\end{array}$ & $\begin{array}{c}\text { Progesterone } \\
\text { (ng/ml) }\end{array}$ & $\begin{array}{c}\text { Cycle length } \\
\text { (days) }\end{array}$ \\
\hline Oxytocin & 3 & $482.8 \pm 91 \cdot 4$ & $4.50 \pm 1 \cdot 11$ & - \\
Oxytocin & 3 & - & $2.53 \pm 1 \cdot 19$ & $16.50 \pm 1 \cdot 0$ \\
Saline & 4 & $589.2 \pm 259$ & - & - \\
Saline & 4 & - & $4.55 \pm 1.09$ & $16.25 \pm 0.5$ \\
\hline
\end{tabular}

Values are means \pm s.e.m. 


\section{Experiment 5}

Treatment with oxytocin twice a day on Days 10-15 after mating did not affect the maintenance of pregnancy in lactating or nonlactating ewes. Gestation continued and lambing occurred in 13 of 17 treated ewes (Table 5).

Table 5. Effect of oxytocin ( 25 i.u. twice a day) or saline $(2.0 \mathrm{ml} ; 0.9 \% \mathrm{NaCl})$ on pregnancy in ewes when injected on Days 10-15 after mating (Exp. 5)

\begin{tabular}{|c|c|c|c|c|c|c|c|}
\hline \multirow[b]{2}{*}{ Treatment } & \multicolumn{2}{|c|}{ Lactating } & \multicolumn{2}{|c|}{ Nonlactating } & \multicolumn{3}{|c|}{ Total } \\
\hline & Pregnant & Nonpregnant & Pregnant & Nonpregnant & $n$ & Pregnant & Nonpregnant \\
\hline Oxytocin & 6 & 2 & 7 & 2 & 17 & 13 & 4 \\
\hline Saline & 3 & 0 & 3 & 0 & 6 & 6 & 0 \\
\hline
\end{tabular}

\section{Discussion}

In the present studies, oxytocin injected twice a day for 4 consecutive days at each stage of the oestrous cycle (Exp. 1) did not affect concentrations of plasma progesterone or the length of the oestrous cycle. Results from Exp. 4 (s.c. oxytocin twice a day on Days 2-6) indicate that CL weight was also unaffected. The absence of luteolytic effects of oxy tocin in our study are in contrast to the results reported by Hatjiminaoglou et al. (1979) that oxytocin injected twice a day during the first week after oestrus resulted in decreased luteal weight and progesterone concentration. Milne (1963) reported histological indications of degeneration of ovine CL after oxytocin treatment early in the oestrous cycle. The reasons for these discrepancies are unknown. However, different breeds of sheep were used in the 3 studies.

Experiments 2 and 3 used mini-osmotic pumps to examine the effects of oxytocin delivered directly into the CL. Infusions were given on Days 2-9, a period when increased concentrations of luteal oxytocin have been reported, and Days 10-15, a period when luteal oxytocin content declines (Sheldrick \& Flint, 1981). In the present studies, infusions at these stages of the oestrous cycle did not affect luteal weight, cycle length or concentration of plasma progesterone.

The results of the present study do not support the concept of direct inhibition by oxytocin on the ovine CL. Numerous studies have examined the effects of oxytocin on progesterone production by ovine (Rodgers et al., 1985), bovine (Tan et al., 1982a) and human (Tan et al., 1982b) CL tissue in vitro; the results have been equivocal. Oxytocin has been reported to both stimulate and inhibit progesterone production or to have no effect.

Flint \& Sheldrick (1985) reported that continuous i.v. infusion of oxytocin on Days 13-21 prolongs the functional lifespan of the $\mathrm{CL}$ and delays the return to oestrus in ewes by $\sim 7$ days. These results are not necessarily contradictory to those in the present study, since the route of administration, days and frequency of treatment, and doses of oxytocin were different; however, there were no indications of a delayed luteolytic process in our ewes.

The results from Exp. 5 indicate that maintenance of pregnancy in lactating and nonlactating ewes is not compromised by exogenous oxytocin given on Days 10-15 after mating. Flint \& Sheldrick (1983) and others have proposed that oxytocin is secreted from the CL in response to PGF from the uterus, oxytocin binds to uterine oxytocin receptors and results in additional PGF. At this time of pregnancy, the concentrations of oxytocin in the CL (Sheldrick \& Flint, 1983) and the number of uterine oxytocin receptors (Sheldrick \& Flint, 1985) have been reported to be low. Sheldrick \& Flint (1985) have established that progesterone is a very effective inhibitor of the induction of uterine oxytocin receptors. In the present study, concentrations of progesterone in 
pregnant ewes increased on about Day 15, compared with those in nonpregnant ewes, and may have blocked any effects of the injected oxytocin.

Our results suggest that ovine and bovine $C L$ respond differently to oxytocin injected s.c. The development and function of bovine CL are inhibited when oxytocin is injected during the first week of the oestrous cycle. This inhibition was associated with increased concentrations of uterine venous PGF in cows (Milvae \& Hansel, 1980) and 13,14-dihydro-15-keto-PGF-2 $\alpha$ in ovariectomized, steroid-treated ewes (Flint et al., 1989). The inhibitory effects of oxytocin on bovine CL function were partly overcome by concurrent indomethacin treatment (Milvae \& Hansel, 1985). In our studies we did not determine concentrations of PGF after oxytocin treatment, but there was no indication of inhibition by oxytocin on the ovine $C L$ when injected during the early stages of the oestrous cycle.

\section{References}

Armstrong, D.T. \& Hansel, W. (1959) Alteration of the bovine estrous cycle with oxytocin. J. Dairy $S c i .42$, 533-542.

Beal, W.E., Milvae, R.A. \& Hansel, W. (1980) Oestrous cycle length and plasma progesterone concentrations after administration of prostaglandin F-2 $\alpha$ early in the bovine oestrous cycle. J. Reprod. Fert, 59, 393-396.

Flint, A.P.F. \& Sheldrick, E.L. (1982) Ovarian secretion of oxytocin is stimulated by prostaglandin. Nature, Lond. 297, 587-588.

Flint, A.P.F. \& Sheldrick, E.L. (1983) Evidence for a systemic role for ovarian oxytocin in luteal regression in sheep. J. Reprod. Fert. 67, 215-225.

Flint, A.P.F. \& Sheldrick, E.L. (1985) Continuous infusion of oxytocin prevents uterine oxytocin receptor and blocks luteal regression in cyclic ewes. $J$. Reprod. Fert. 75, 623-631.

Flint, A.P.F., Sheldrick, E.L., Jones, D.S.C. \& Auletta, F.J. (1989) Adaptations to pregnancy in the interactions between luteal oxytocin and the uterus in ruminants. J. Reprod. Fert., Suppl. 37, 195-204.

Gill, J.L. \& Hafs, H.D. (1971) Analysis of repeated measurements of animals. J. Anim. Sci. 33, $331-336$.

Hatjiminaoglou, P.I., Alifakiotis, T. \& Zervas, N. (1979) The effect of exogenous oxytocin on estrous cycle length and corpus luteum lysis in ewes. Ann. Biol. anim. Biochim. Biophys. 19, 355-365.

Milne, J.A. (1963) Effects of oxytocin on the oestrous cycle of the ewe. Aust. vet. J. 51-52.

Milvae, R.A. \& Hansel, W. (1980) Concurrent uterine venous and ovarian arterial prostaglandin $F$ concentrations in heifers treated with oxytocin. J. Reprod. Fert. 60, 7-15.
Milvae, R.A. \& Hansel, W. (1985) Inhibition of bovine luteal function by indomethacin. J. Anim. Sci. 60, $528-531$.

Rodgers, R.J., O'Shea, J.D. \& Findlay, J.K. (1985) Do small and large luteal cells of the sheep interact in the production of progesterone? J. Reprod. Fert. 75, 85-94.

Schams, D., Schallenberger, E., Meyer, H.H.D., Bullermann, B., Breitinger, H., Enzenhofer, G., Kol, R., Druip, Th.A.M., Walters, D.L. \& Karg, H. (1985) Ovarian oxytocin during the oestrous cycle in cattle. In Oxytocin, Clinical and Laboratory Studies, pp. 317-334. Eds J. A. Amico \& A. G. Robinson. Excerpta Medica, Amsterdam.

Sheldrick, E.L. \& Flint, A.P.F. (1981) Circulating concentrations of oxytocin during the estrous cycle and early pregnancy in sheep. Prostaglandins 22, 63I-636.

Sheldrick, E.L. \& Flint, A.P.F. (1983). Luteal concentrations of oxytocin decline during early pregnancy in the ewe. J. Reprod. Feri. 68, 477-480.

Sheldrick, E.L. \& Flint, A.P.F. (1985) Endocrine control of oxytocin receptors in the ewe. J. Endocr. 106, 249-258.

Tan, G.J.S., Tweedale, R. \& Biggs, J.S.G. (1982a) Effects of oxytocin on the bovine corpus luteum of early pregnancy. J. Reprod. Fert. 66, 75-78.

Tan, G.J.S., Tweedale, R. \& Biggs, J.S.G. (1982b) Oxytocin may play a role in the control of the human corpus luteum. J. Endocr. 95, 65-70.

Wathes, D.C. (1984) Possible actions of gonadal oxytocin and vasopressin. J. Reprod. Fert. 71, 15-345.

Wathes, D.C. \& Swann, R.W. (1982) Is oxytocin an ovarian hormone? Nature, Lond. 297, 225-227.

Received 27 July 1990 